\title{
Climate change reflected in one of the largest wetlands in the world: an overview of the Northern Pantanal water regime
}

\author{
Mudança climática refletida em uma das maiores áreas úmidas do mundo: uma visão
} geral do regime das águas do Pantanal do Norte

\author{
Wilkinson Lopes Lázaro ${ }^{1 *}$ (D), Ernandes Sobreira Oliveira-Júnior ${ }^{1 *}$ (D), \\ Carolina Joana da Silva ${ }^{1}$ (D), Solange Kimie Ikeda Castrillon ${ }^{1}$ (D), Claumir César Muniz ${ }^{1}$ \\ ${ }^{1}$ Programa de Pós-Graduação em Ciências Ambientais, Centro de Estudos em Limnologia, \\ Biodiversidade e Etnobiologia do Pantanal, Universidade do Estado de Mato Grosso - UNEMAT, \\ Campus de Cáceres, CEP 78200-000, Cáceres, MT, Brasil. \\ * e-mail: ernandes.sobreira@gmail.com
}

Cite as: Lázaro, W. L. and Oliveira-Júnior, E. S et al. Climate change reflected in one of the largest wetlands in the world: an overview of the Northern Pantanal water regime. Acta Limnologica Brasiliensia, 2020, vol. 32, e104.

\begin{abstract}
The dynamics of Pantanal is totally influenced by the flood pulse, which is, in part, a consequence of rainfall regime from the Amazon in the direction to the headlands and the lowlands where the water is retained, and the flood plain is formed. The impacts of climate change have not yet been measured for the Northern Pantanal (Pantanal of Cáceres), where it is the gateway to most Pantanal waters. Here, we have used rainfall, hydrology, and satellite imagery data to ascertain the possible rainfall patterns, water retention, and level of the Paraguay River over the past decades. Although a well-defined water pulse is found in the Northern Pantanal, over a 42-year historical series the number of days without precipitation has greatly increased, as well the loss of water mass in the landscape over the last 10 years specifically in during the drought season. Overall, nowadays the Northern Pantanal has 13\% more days without rain than in the 60's, and the water mass is $16 \%$ less during the drought season considering the last 10 years. These results show that nowadays the Pantanal is losing water and experiencing a more severe drought season than in the past. Regarding the physicochemical and biological cycles of the ecosystem, these changes can result in the loss of biodiversity, as well as the loss of ecosystem services, intrinsically linked to the flood pulse. Given that these losses have been aggravated by anthropogenic pressures (e.g. deforestation, erosion, hydroelectric power stations), the drafting of strategic plans for safeguarding wildlife and human populations, as well as agriculture, cattle raising, fisheries and the preservation of the people's lifestyle in the Pantanal must be urgently implemented.
\end{abstract}

Keywords: tropical wetland; ecosystem regulation; flooding reduction; drought season extension.

Resumo: A dinâmica do Pantanal é totalmente influenciada pelo pulso de inundação, o qual é, em parte, uma consequência do regime de chuvas da Amazônia na direção das cabeceiras e planícies onde a água é retida e a planície formada. Os impactos das mudanças climáticas, embora consensualmente aceitos, ainda não foram medidos no Pantanal do Norte (Pantanal de Cáceres), que é a porta de entrada para a maioria das águas do Pantanal. Aqui, usamos dados de precipitaçáo, hidrologia e imagens de satélite para verificar os possíveis padróes de precipitação, retenção de água e nível do rio Paraguai nas últimas décadas. Embora seja encontrado um pulso de inundação bem definido no Pantanal do Norte, ao longo de uma série histórica de 42 anos, o número de dias sem precipitação aumentou muito, assim como a perda de massa de água na paisagem nos últimos 10 anos, especificamente 
durante a estaçáo seca. No geral, hoje em dia o Pantanal Norte tem 13\% a mais de dias sem chuva do que nos anos 60, e a massa de água é $16 \%$ menor durante a estação da seca, considerando os últimos 10 anos. Esses resultados mostram que o Pantanal está perdendo água e passando por uma seca mais severa hoje em dia do que no passado. No que diz respeito aos ciclos físico-químicos e biológicos do ecossistema, essas mudanças podem resultar na perda de biodiversidade, bem como na perda de serviços ecossistêmicos, intrinsecamente ligados ao pulso de inundação. Dado que essas perdas foram agravadas por pressões antropogênicas (por exemplo, desmatamento, erosão, usinas hidrelétricas), a elaboração de planos estratégicos para salvaguardar a vida selvagem e as populaçóes humanas, assim como a agricultura, a pecuária, a pesca e a preservação do estilo de vida das pessoas do Pantanal devem ser implementados com urgência.

Palavras-chave: áreas alagáveis tropicais; regulação ecossistêmica; redução da inundação; extensão a estiagem.

The flood pulse of the Pantanal is highly fed by not only the local precipitation, but by the rain in the headwaters where the Paraguay river, the main water channel of the Pantanal, slowly conducts the water downstream (Junk \& Wantzen, 2004; Junk et al., 2014). The flat morphology of the Pantanal and the gentle slope of the Paraguay river are especially important for the seasonal lateral inundation processes. The water mostly enters the Pantanal from the North (Da Silva \& Girard, 2005), where the rainfall is converted into runoff (Bravo et al., 2012), and the river bank overflows connecting water bodies (Gonçalves et al., 2011) feeding and forming lakes (Loverde-Oliveira et al., 2007). Naturally, the water bodies of the Pantanal are shallow, which is a natural response of the sedimentary deposition character of the area, both in the river and in the surrounding lakes (caused by the low and flat topography and the associated slow flow of the Paraguay river) (Assine \& Soares, 2004; Assine, 2005; Gonçalves et al., 2011).

However, the inundation pattern of the Pantanal has been changing. For years researchers have shown that the Pantanal is sensitive to environment transformation, where faster flow and increased sediment loading may harm the inundation of the Pantanal (Hamilton, 2002; Junk et al., 2012, 2014; De Campos et al., 2020). Direct activities in the catchment area of the Pantanal, as the construction of dams (Da Silva \& Girard, 2005; Da Silva et al., 2015), and in the Paraguay River itself, as the waterway implementation (Gottgens et al., 2001) impact the Pantanal inundation patterns. Moreover, we argue that the association of the direct activities and the climate change exert a fundamental effect on the river water level and the inundation time implying in serious consequences to the flood pulse of the Pantanal.

Predictions of the decrease in the precipitation and increase of the temperature for the South
American wetlands have been indicated since the document published with climatic data for all the world (WMO, 2006). Also, rainfall declining trends for southern Amazon were detected by Davidson and colleagues (Davidson et al., 2012). Studies related to climate change, show the temporal displacement of the rainy season and its decrease in the south of the Amazon and Pantanal. (Debortoli, et al., 2016).

Studies published by a Brazilian Climate Networking showed that the whole country of Brazil has faced extreme climatic events from the last 10 years (Araújo et al., 2019). For instance, these extreme events in the Pantanal highly affect the Paraguay river hydrodynamics, which has a very intricated and synergetic relation to precipitation regime - altering the flooding time, water retention and processes regulation of the biodiversity and ecosystem services (Bravo et al., 2012).

Hereby we present the analysis of hydrologic data available from national and international institutes for the northernmost area of the Pantanal - 834,000 ha (Figure 1 - Pantanal of Cáceres according to Silva \& Abdon (1998); here called as Northern Pantanal). 1) Precipitation: we used the Instituto Nacional de Meteorologia - INMET/Station Cáceres-A941; 2) Paraguay river level: we used the Marinha do Brasil Agência Fluvial de Cáceres/MT open data; 3) Water mass area: for the difference in water mass we used a total of 62 composite images, product MOD13Q1, from 2008 to 2018, acquired by the MODIS sensor and stored in Earth Engine Plataform. These images had the spatial resolution of 250 metres, with temporal resolution of 16 days, and spectral resolution of four reflectance bands (blue, red, NIR, MIR). The images were aggregated into a mosaic, cut out, redesigned (WGS84, UTM, zone 21) and converted in a radiometric resolution from 16 to 8 bits. Afterwards, we collected pure 


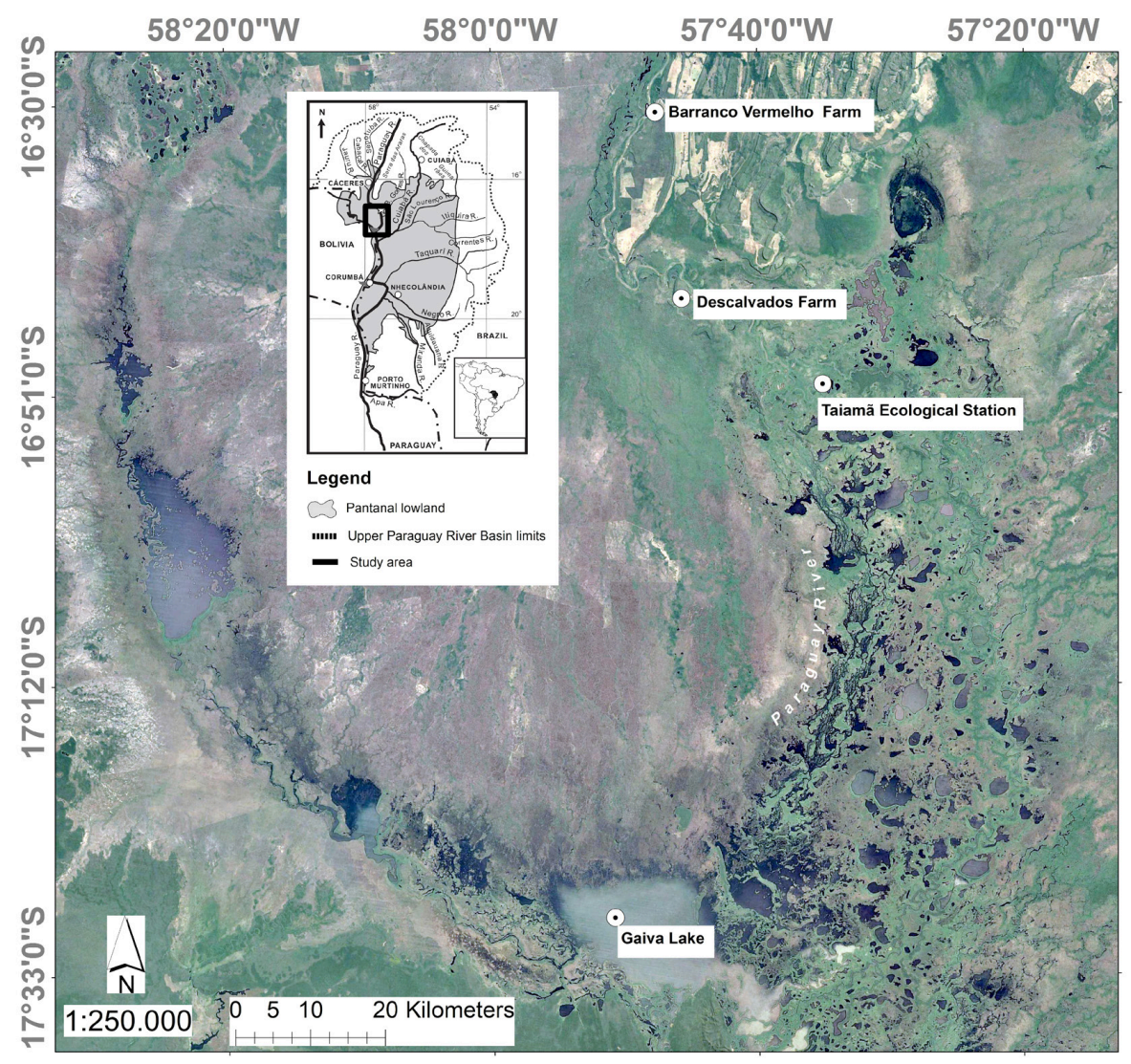

Figure 1. Location of the studied area and representation of the water mass area of the Northern Pantanal in the Upper Paraguay River Basin (01/10/2008).

pixels (from the medium infrared (MIR) and the blue band, for the vegetation, soil and water endmembers, respectively), to apply the Linear Spectral Mixing Model (MLME), followed by the slicing of water fraction images histogram ("water" and "non-water" classes). Once the classes were delimited, they were manually edited for errors in the classification. The analyses were carried out using the MRT (MODIS Reprojection Tool), ConvGeoTif, SPRING and ArcGIS softwares. The spectral curves obtained for each MLME endmember fit with the standard spectral curves expected for the vegetation (Ponzoni, 2001), soil (Netto, 2001) and water (Novo, 2001) endmembers, in the blue, red, NIR and MIR reflectance bands. The products were used to calculate the water mass area, considering the months of March (full flood) and August (drought) in each year.

We considered the historical series from 1971 to 2013 for the precipitation (period of data available - CáceresA941 Station), excluding the years of lack of information (where not all the months of the year were available); for water level we used the data from 1971 to 2013 to compare with the precipitation. To analyze the seasons of the Northern Pantanal, we compared the monthly water level using a cluster dendrogram with the Euclidian distance, and UPGMA (Unweighted Pair Group Method using Arithmetic averages) algorithm (Michener \& Sokal, 1957), showing the relation between the months. Afterwards, we grouped them into four hydrological seasons (drought, flooding, full flood and ebb). We used linear regressions to investigate the hydrological pulse and the precipitation throughout the years.

We noticed that the Northern Pantanal has a well-defined water dynamic considering a historical series of 42 years. According to our analysis (cluster) this water level dynamic can be divided in three months (Figure 2A) for each hydrological season - drought, flooding, full flood and ebb. The drought has significantly lower water depth than the full flood $(\mathrm{P}<0.05$; Figure $2 \mathrm{~B})$ characterizing the flood pulse.

The seasonal variation of the water body corresponds to the water expansion from the drought to the wet seasons. The area of the Pantanal is approximately $140,000 \mathrm{~km}^{2}$ (Mioto et al., 2019), 


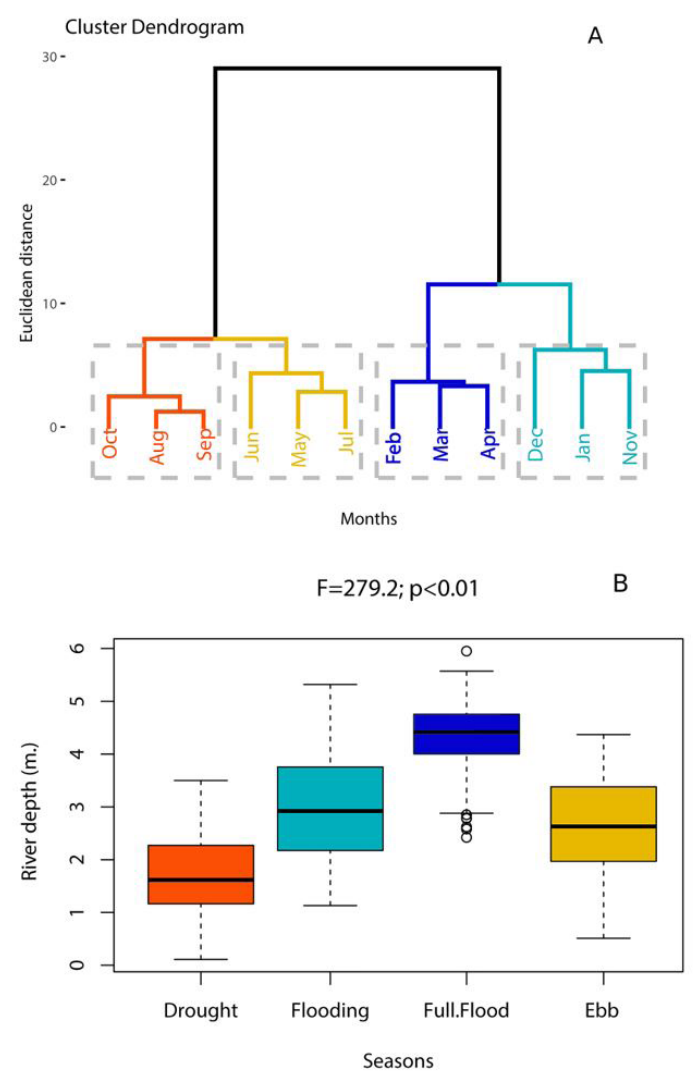

Figure 2. Hydrological period of the Northern Pantanal showing the differences between the months $(\mathrm{A})$ and the seasons (B) considering a time series from 1971 to 2013. Note: same colors were used to differentiate hydrological periods. on which the maximum area subject to flooded may reach $131,000 \mathrm{~km}^{2}$ during the wet season (Hamilton et al., 2002). In the Northern Pantanal, in an area of 834,000 ha, the historical landscape data (from 2008 to 2018) show that the mean expansion of the water mass in the landscape (permanent water bodies and temporary flooded areas), increases from $12.1 \%(101,384 \mathrm{ha})$ of the area in the drought season, to $48.9 \%(407,977 \mathrm{ha})$ in the full flood. There are no differences between the water mass percentage in the landscape for the month of March (peak of full flood) from 2008 to 2018, which shows a consistent temporal flood pattern $\left(\mathrm{R}^{2}=0.04\right.$; $\mathrm{P}>0.05)$. However, when analysing the data for the month of August (peak of the drought season) in the same years, there is a significant drop in the water mass area $\left(\mathrm{R}^{2}=0.66 ; \mathrm{P}>0.05\right)$, which means that the Northern Pantanal has been gradually losing water in recent years. The water mass area in August/2008 was 112,590 ha, while in 2018 this area was reduced to 95,076 ha, representing a loss of $16 \%$ of flooded area in ten years (Figure 3 ).

This substantial water mass decrease can be a response of the decrease in precipitation. Although the Pantanal maintains the same precipitation volume $(\mathrm{mm})$ throughout a historical series of 42 years $\left(\mathrm{R}^{2}=0.03 ; \mathrm{P}>0.05\right)$, the number of days without precipitation has increased $\left(\mathrm{R}^{2}=0.70\right.$; $\mathrm{P}<0.05$; Figure 4). In 1981 only 146 days were

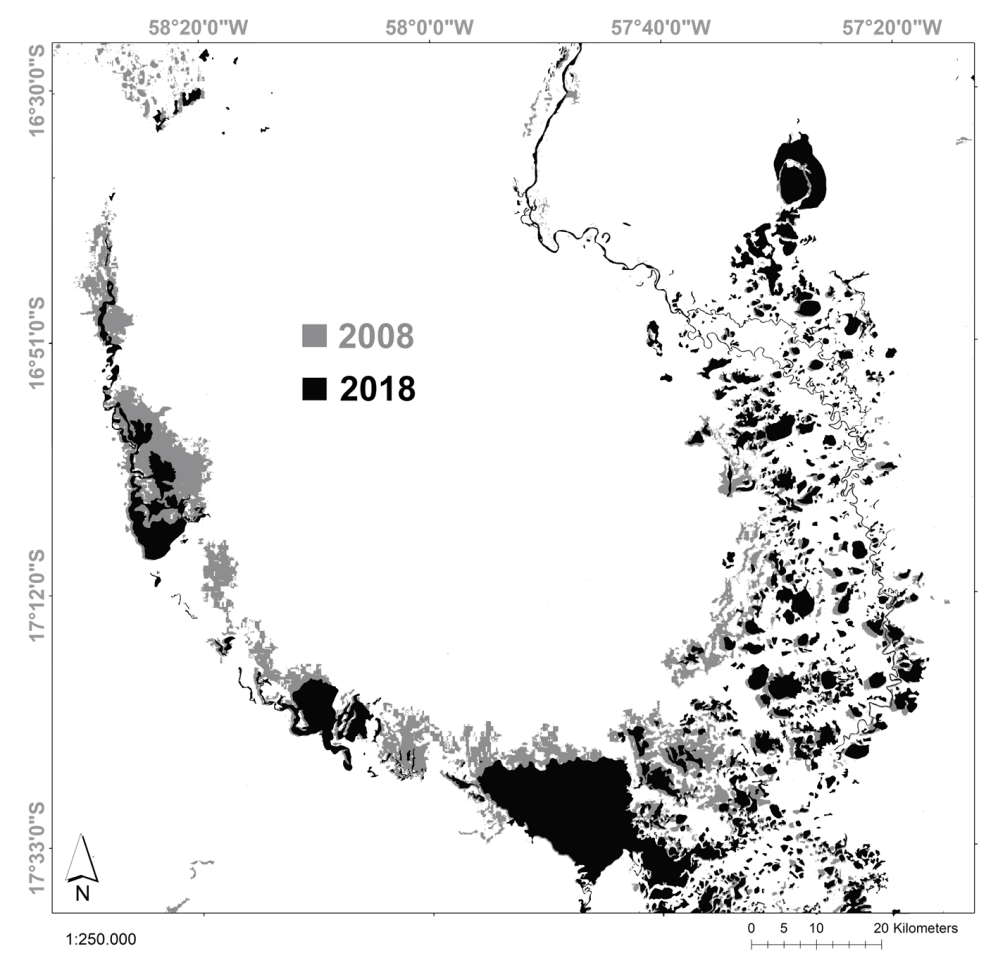

Figure 3. Water mass area in 2008 (grey) and in 2018 (black). 
found without rain, increasing to 248 days in 2001, and 287 days in 2011. This accretion represents from 2 to $6 \%$ of days without precipitation per decade. Previous research showed that in the Paraguay river basin the less amount of rain significantly reduces the river flow, making the drought season more persistent (Collischonn et al., 2001). The same authors also showed that the Paraguay river basin had a severe drought period in the past ( 60 's), preceded by the raising in water for the further years. However, the rising waters after the 70's reduced in the further decades (Figure 4). In fact, water has been reduced in the Brazilian tropical forests nowadays. Recent studies have found a decrease in both precipitation (Marengo \& Espinoza, 2016) and water surface area in Amazon (Souza Junior et al., 2019), showing a conversion from water to land in years of extreme droughts.

Considering that the hydrological cycle in the Northern Pantanal is well related to the precipitation $\left(R^{2}=0.20 ; p<0.05\right.$; Figure 5A), these longer periods without rain tends to decrease the river depth (Figure 5B), which consequently affect the floodplain as a total. A decrease in the Northern portion of the Paraguay river depth by 10 to $25 \mathrm{~cm}$ reduce the flooded area by 8 to $18 \%$, respectively, being one of the most sensitive area for the flooding reduction in the Pantanal (Hamilton, 1999). Overall, scenarios of water deficit in the Pantanal (based on IPCC data) may raise in the $21^{\text {st }}$ century, reducing the extension of the flood pulse (Marengo et al., 2015).

The reduction in water mass and precipitation, consequently affecting the river depth and its overflow, harm the ecological process (e.g. fish reproduction, marginal plant phenology and fish seeds dispersal (Alho et al., 2019). Moreover, the delay on precipitation and the condensed water area during the drought season affects the breeding of many species, such as fish, mammals, birds that reproduce during the spring (Alho, 2008, Leuchtenberger et al., 2013). Analysis of the precipitation data for the Southern Amazon, reaching the Pantanal Wetland biome, more than 200 Rain Gauges showed a delay for the onset of the rainy season in $76 \%$ in a series from 1971 to 2010 (Debortoli et al., 2016). These trends were also verified in other studies on Pantanal, evaluating the perceptions of traditional people about the climate change perception. The Pantanal's population identify a historic change in temperature and precipitation, as a decrease, delay and shorter rainy season months in the last decade (Da Silva et al., 2014).
This water reduction due to a decrease in precipitation may cause a cascade effect. For instance, the lower the water mass, the smaller is the habitat area for macroinvertebrates and fish (Zerlin \& Henry, 2014). The dispersal of seeds potentially produced by fish (Ruxton \& Schaefer, 2012)

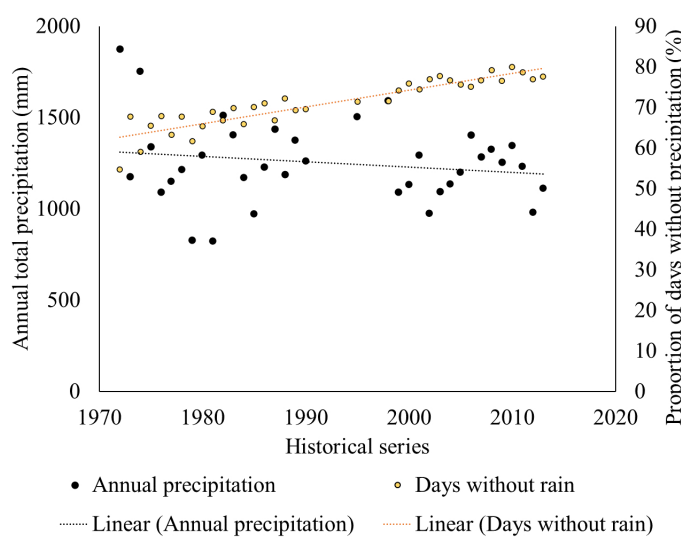

Figure 4. Total precipitation per year occurring in the Northern Pantanal from 1971 to 2013 - black dots; and the proportion of days without precipitation - yellow dots. The proportion was calculated by the variation in the numbers of days per years available in the data set.
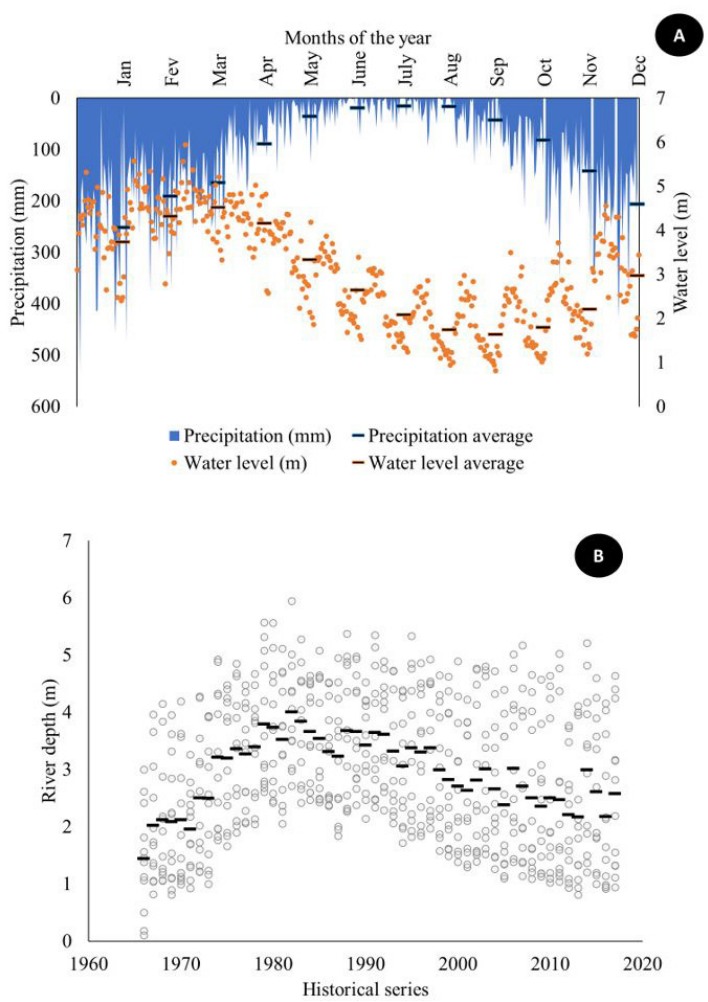

Figure 5. Monthly precipitation and Paraguay river water level in the Northern Pantanal from 1971 to 2013 (A); and Annual Paraguay river depth in the same region from 1971 to 2013 (B) showing the flood pulse of the waters. Black dashes represent the annual average. 
diminish the range to the flat area of the Pantanal, affecting the vegetation recomposition. The nutrient mineralization of the organic matter provided by the vegetation, dependent of the difference in the seasons (Vourlitis et al., 2017), changes the soil/sediment composition. The "pantaneiros", people that were born in Pantanal and have deep connection and dependence of the flood pulse dynamics for their strategies of life, will be most affected by these changes (Da Silva and Silva, 1995, Da Silva et al., 2014).

The Driver, Pressure, States, Impacts and Responses (DPSIR) analysis made for the Pantanal/Upper Paraguay Basin and Guapore/Amazon Basin showed the most important drivers in these systems were the energy and land use policies, with the pressure represented by hydropower and agriculture system in large scale. The studies also showed the loss of the hydrological horizontal connectivity as the main negative impact, converting the transitional ecotone zone to livestock and degraded systems areas among Amazon-Cerrado-Pantanal (Da Silva et al.,2015).

A major threat in the Pantanal is the economic pressure imposed by the agribusiness sector outside the region. The Paraguay-Paraná waterway project for cheap commercial shipping of soybeans and minerals to the Atlantic Ocean, and the river dredging for the passage of commercial boats, can lead to a decrease in water retention time in the area. These circumstances, in addition to the decrease in rainy days, eventually changes large-scale wetlands hydrology, seriously affecting the living conditions of biological populations.

Another point to be considered is the drought landscape use for new agriculture implementation. The deforestation in the upper Pantanal has highly increased in the recent years (Silva et al., 2011). Soybeans plantation has arrived in the Pantanal lowland (Silva \& Lima 2018), which is favored by an increase in the area suitable for plantation if the water mass keeps reducing. In the Araguaia river, a possible cause of extreme drought events is associated to less precipitation and anthropogenic activities, reducing the river water and increasing the exposure of sand banks (Fleischmann et al., 2017). It is well known the relation of this activity impacts to the water quality, hydric contamination by the pesticides, introduction of invasive species, erosions and siltation, and its effects in the Pantanal potentially harms this sensible Biome.

Hereby we presented the data and a discussion showing that the Pantanal has diminished the water mass during the drought season where the reduction in precipitation had a great effect. Even more drastic than the water mass reduction due to the scarcity of rainy days is the water mass reduction during the drought season. We argue that if the drop in water mass continues, it may force the population, the government and the scientists to drive efforts in the direction to keep the Pantanal as a wet land, taking into consideration these threats in the implementation of regional plans. More than ever, the importance of the Pantanal as a hydrological buffer system for downstream areas, a regional climate regulator, a valuable water retention and purification area, and a biodiversity maintenance center should be recognized. Although facing the current implications in the Brazilian environmental law, we claim that attention needs to be given to this sensitive biome, and that the policies of the decision makers take into consideration the importance of the Pantanal to the world.

\section{Acknowledgements}

We would like to thank the Chico Mendes Institute for Biodiversity Conservation (ICMBio) for fieldwork support. We also thank the Coordination for the Improvement of Higher Education Personnel (CAPES) for granting the Postdoctoral (Wilkinson Lopes Lázaro) and productivity (Carolina Joana da Silva) grants, within the scope of the Long Duration Ecological Research Project (PELD/DARP).

\section{References}

ALHO, C.J.R. Biodiversity of the Pantanal: Response to seasonal flooding regime and to environmental degradation. Brazilian Journal of Biology = Revista Brasileira de Biologia, 2008, 68(4 Suppl.), 957-966. http://dx.doi.org/10.1590/S1519. 69842008000500005. PMid:19197468.

ALHO, C.J.R., MAMEDE, S.B., BENITES, M., ANDRADE, B.S. and SEPÚLVEDA, J.J.O. Threats to the biodiversity of the brazilian pantanal due to land use and occupation. São Paulo: Ambiente \& Sociedade, 2019, $22 \mathrm{p}$.

ARAUJO, M., OMETTO, J. and SOARES, A.P., orgs. Impactos das Mudanças climáticas no Brasile caminhos para a sustentabilidade. São Paulo: Rede Clima, 2019.

ASSINE, M.L. River avulsions on the Taquari megafan, Pantanal wetland, Brazil. Geomorphology, 2005, 70(3-4), 357-371. http://dx.doi.org/10.1016/j. geomorph.2005.02.013.

ASSINE, M.L. and SOARES, P.C. Quaternary of the Pantanal, west-central Brazil. Quaternary International, 2004, 114(3), 23-34. http://dx.doi. org/10.1016/S1040-6182(03)00039-9. 
BRAVO, J.M., ALLASIA, D., PAZ, A.R., COLLISCHONN, W. and TUCCI, C.E.M. Coupled Hydrologic-Hydraulic Modeling of the Upper Paraguay River Basin. Journal of Hydrologic Engineering, 2012, 17(5), 635-646. http://dx.doi. org/10.1061/(ASCE)HE.1943-5584.0000494.

COLLISCHONN, W., TUCCI, C.E.M. and CLARKE, R.T. Further evidence of changes in the hydrological regime of the River Paraguay: part of a wider phenomenon of climate change? Journal of Hydrology (Amsterdam), 2001, 245(1-4), 218-238. http:// dx.doi.org/10.1016/S0022-1694(01)00348-1.

DA SILVA, C.J. and SILVA, J.A.F. No ritmo das águas do Pantanal. São Paulo: NUPAUB, 1995.

DA SILVA, C.J. and GIRARD, P. New challenges in the management of the Brazilian Pantanal and catchment area. Wetlands Ecology and Management, 2005, 12(6), 553-561. http://dx.doi.org/10.1007/ s11273-005-1755-0.

DA SILVA, C.J., ALBERNAZ-SILVEIRA, R. and NOGUEIRA, P.S. Perceptions on climate change of the traditional community Cuiabá Mirim, Pantanal Wetland, Mato Grosso, Brazil. Climatic Change, 2014, 127(1), 83-92. http://dx.doi.org/10.1007/ s10584-014-1150-z.

DA SILVA, C.J., SILVA SOUSA, K.N., IKEDACASTRILLON, S.K., LOPES, C.R.A.S., SILVA NUNES, J.R., CARNIELLO, M.A., MARIOTTI, P.R., LAZARO, W.L., MORINI, A., ZAGO, B.W., FAÇANHA, C.L., ALBERNAZ-SILVEIRA, R., LOUREIRO, E., VIANA, I.G., OLIVEIRA, R.F., ALVES DA CRUZ, W.J., DE ARRUDA, J.C., SANDER, N.L., FREITAS JUNIOR, D.S., PINTO, V.R., DE LIMA, A.C. and JONGMAN, R.H.G. Biodiversity and its drivers and pressures of change in the wetlands of the Upper Paraguay-Guaporé Ecotone, Mato Grosso (Brazil). Land Use Policy, 2015, 47, 163-178. http://dx.doi.org/10.1016/j. landusepol.2015.04.004.

DAVIDSON, E.A., DE ARAÚJO, A.C., ARTAXO, P., BALCH, J.K., BROWN, I.F., BUSTAMANTE, M.M.C., COE, M.T., DEFRIES, R.S., KELLER, M., LONGO, M., MUNGER, W., SCHROEDER, W., SOARES-FILHO, B.S., SOUZA, C.M. and WOFSY, S.C. The Amazon basin in transition. Nature, 2012, 481, 321-328. https://doi.org/10.1038/nature10717.

DE CAMPOS, M., TRITICO, H.M., GIRARD, P., ZEILHOFER, P., HAMILTON, S.K. and FANTIN囚CRUZ, I. Predicted impacts of proposed hydroelectric facilities on fish migration routes upstream from the Pantanal wetland (Brazil). River Research and Applications, 2020, 36(3), 1-13. http:// dx.doi.org/10.1002/rra.3588.

DEBORTOLI, N.S., DUBREUIL, V., HIROTA, M., FILHO, S.R., LINDOSO, D.P. and NABUCET, J. Detecting deforestation impacts in Southern Amazonia rainfall using rain gauges. International
Journal of Climatology, 2016, 37(6), 2889-2900. http://dx.doi.org/10.1002/joc.4886.

FLEISCHMANN, A.S., MATTIUZI, C.D.P., KICH, E M., GONDIM, G., RUHOFF, A. and PAIVA, R. Avaliação da seca de 2016 do Rio Javaés (bacia do Rio Araguaia) com uso de dados de múltiplos satélites. In: Anais do XVII Simpósio Brasileiro de Sensoriamento Remoto. Santos: INPE, 2017, pp. 5033-5040.

GONÇALVES, H., MERCANTE, M. and SANTOS, E. Hydrological cycle. Brazilian Journal of Biology = Revista Brasileira de Biologia, 2011, 71(1 Suppl.), 241-253. http://dx.doi.org/10.1590/S151969842011000200003. PMid:21537597.

GOTTGENS, J.F., PERRY, J.E., FORTNEY, R.H., MEYER, J.E., BENEDICT, M. and ROOD, B.E. The Paraguay-Paraná Hidrovía: Protecting the Pantanal with Lessons from the Past. Bioscience, 2001, 51(4), 301-308. http://dx.doi.org/10.1641/00063568(2001)051[0301:TPPHAP]2.0.CO;2.

HAMILTON, S.K. Potential effects of a major navigation project (Paraguay-Parana Hidrovia) on inundation in the Pantanal floodplains. Regulated Rivers: Research and Management, 1999, 15(4), 289-299. http://dx.doi.org/10.1002/ (SICI) 1099-1646(199907/08) 15:4<289::AIDRRR520>3.0.CO;2-I.

HAMILTON, S.K. Human impacts on hydrology in the pantanal wetland of South America. Water Science and Technology, 2002, 45(11), 35-44. http://dx.doi. org/10.2166/wst.2002.0377. PMid:12171364.

HAMILTON, S.K., SIPPEL, S.J. and MELACK, J.M. Comparison of inundation patterns among major South American floodplains. Journal of Geophysical Research, 2002, 107(D20, 8038), 31-44.

JUNK, W.J. and WANTZEN, K.M. The flood pulse concept: new aspects, approaches and applications an update. In: Proceedings of the Second International Symposium on the Management of Large Rivers for Fisheries. FAO, 2004, pp. 117-149.

JUNK, W.J., MITSCH, W.J., GOPAL, B., MITCHELL, S.A. and FINLAYSON, C.M. Current state of knowledge regarding the world's wetlands and their future under global climate change: a synthesis. Aquatic Sciences, 2012, 75(1), 151-167. http://dx.doi. org/10.1007/s00027-012-0278-z.

JUNK, W.J., PIEDADE, M.T.F., LOURIVAL, R., WITTMANN, F., KANDUS, P., LACERDA, L.D., BOZELLI, R.L., ESTEVES, F.A., NUNES DA CUNHA, C., MALTCHIK, L., SCHÖNGART, J., SCHAEFFER-NOVELLI, Y. and AGOSTINHO, A.A. Brazilian wetlands: Their definition, delineation, and classification for research, sustainable management, and protection. Aquatic Conservation, 2014, 24(1), 5-22. http://dx.doi.org/10.1002/ aqc. 2386 . 
LEUCHTENBERGER, C., OLIVEIRA-SANTOS, L.G.R., MAGNUSSON, W. and MOURÃO, G. Space use by giant otter groups in the Brazilian Pantanal. Journal of Mammalogy, 2013, 94(2), 320-330. http://dx.doi.org/10.1644/12MAMM-A-210.1.

LOVERDE-OLIVEIRA, S.M., HUSZAR, V.L.M. and FANTIN-CRUZ, I. Implications of the flood pulse on morphometry of a Pantanal lake (Mato Grosso state, Central Brazil). Acta Limnologica Brasiliensia, 2007, 19(4), 453-461.

MARENGO, J.A., ALVES, L.M. and TORRES, R.R. Regional climate change scenarios in the Brazilian Pantanal watershed. Climate Research, 2015

MARENGO, J.A. and ESPINOZA, J.C. Extreme seasonal droughts and floods in Amazonia: causes, trends and impacts. International Journal of Climatology, 2016, 36(3), 1033-1050. http://dx.doi. org/10.1002/joc. 4420 .

MICHENER, C.D. and SOKAL, R.R. A quantitative approach to a problem of classification. Evolution; International Journal of Organic Evolution, 1957, 11(2), 490-499. http://dx.doi. org/10.1111/j.1558-5646.1957.tb02884.x.

MIOTO, C.L., AMORIM, G., MACHADO, R., DALMAS, F.B., OLIVEIRA, A.P.G., SAAD, A.R., DIODATO, M.A. and FILHO, A.C.P. Neotectonics as a structural control of the boundaries of the Pantanal Matogrossense Sub-Regions. Anais da Academia Brasileira de Ciências, 2019, 91(1), 1-12. http://dx.doi.org/10.1590/00013765201920170697. PMid:30994746.

NETTO, J.S.M. Comportamento Espectral dos Solos. In: P.R. MENESES and J.S.M. NETTO, orgs. Sensoriamento Remoto - Reflectância dos Alvos Naturais. Brasília/Planaltina: UnB/Embrapa Cerrados, 2001. cap. 4, p. 127-154.

NOVO, E.M.L.M. Comportamento Espectral da Água. In: P.R. MENESES and J.S.M. NETTO, orgs. Sensoriamento Remoto - Reflectância dos Alvos Naturais. Brasília/Planaltina: UnB/Embrapa Cerrados, 2001. p. 203- 222.

PONZONI, F.J. Comportamento Espectral da Vegetação. In: P.R. MENESES and J.S.M. NETTO, orgs. Sensoriamento Remoto - Reflectância dos Alvos Naturais. Brasília/Planaltina: UnB/Embrapa Cerrados, 2001. p. 157-199
RUXTON, G.D. and SCHAEFER, M.H. The conservation physiology of seed dispersal. Philosophical Transactions of the Royal Society of London. Series B, Biological Sciences, 2012, 367(1596), 17081718. http://dx.doi.org/10.1098/rstb.2012.0001. PMid:22566677.

SILVA, J.S.V. and ABDON, M.M. Delimitação do Pantanal Brasileiro e Suas Sub-Regióes. Pesquisa Agropecuária Brasileira, 1998, 33, 1703-1711.

SILVA, C.A. and LIMA, M. Soy Moratorium in Mato Grosso: Deforestation undermines the agreement. Land Use Policy, 2018, 71, 540-542. http://dx.doi. org/10.1016/j.landusepol.2017.11.011.

SILVA, J.V.S., ABDON, M., SILVA, S.M. and MORAES, J.A. Evolution of Deforestation in the Brazilian Pantanal and Surroundings in the Timeframe 1976 -2008. Geografia, 2011, 36, 35-55.

SOUZA JUNIOR, C.M., KIRCHHOFF, F.T., OLIVEIRA, B.C., RIBEIRO, J.G. and SALES, M.H. Long-Term Annual Surface Water Change in the Brazilian Amazon Biome: Potential Links with Deforestation, Infrastructure Development and Climate Change. Water (Basel), 2019, 3(11), 566. http://dx.doi.org/10.3390/w11030566.

VOURLITIS, G.L., HENTZ, C.S., PINTO JUNIOR, O.B. CARNEIRO, E. and NOGUEIRA, J.S. Soil N, $\mathrm{P}$, and $\mathrm{C}$ dynamics of upland and seasonally flooded forests of the Brazilian Pantanal. Global Ecology and Conservation, 2017, 12, 227-240. http://dx.doi. org/10.1016/j.gecco.2017.11.004.

WORLD METEOROLOGICAL ORGANIZATION - WMO. Statement on the status of the global climate in 2005. Geneva, Switzerland: WMO, 2006, 998 p.

ZERLIN, R. and HENRY, R. Does water level affect benthic macro-invertebrates of a marginal lake in a tropical river-reservoir transition zone? Brazilian Journal of Biology $=$ Revista Brasileira de Biologia, 2014, 74(2), 408-419. http://dx.doi. org/10.1590/1519-6984.26812. PMid:25166325.

Received: 29 August 2019 Accepted: 23 June 2020

Associate Editors: André Megali Amado, Joyce Andreia dos Santos, Rafael Marques Almeida, Simone Jaqueline Cardoso 